\title{
Bank Financing of the Recovery
}

\author{
R. ALTON GILBERT
}

$\mathbb{W}_{\text {H }}$

HILE recovery periods display many common characteristics, each such period has its own unique features which distinguish it from other recoveries. A unique feature of the current recovery period is the lack of growth of bank loans. In previous rem coveries, total loans of commercial banks have increased soon after recession troughs; in the current recovery period, total loans have remained essentially unchanged since the March 1975 trough in economic activity.

Even more uncharacteristic of previous recovery periods is the pattern of business loans at commercial banks. In contrast to the increases posted in previous recoveries, commercial bank business loans have declined in the current recovery. Since March of last year, business loans at commercial banks have declined at a 5 percent annual rate, compared to a 5.5 percent rate of increase for comparable phases of previous recoveries. In addition, the rate of decline in business lending by the larger commercial banks has been more rapid than for the rest of the banking system; since March of last year commercial and industrial loans of weekly reporting banks have declined at a 9.5 percent annual rate.

This pattern of bank lending raises some important questions for public policy. Have banks become more conservative in their lending practices than in the past? Is the relative lack of bank financing likely to hamper continued economic recovery? Have businesses developed alternative sources of credit? How have these developments influenced the ability of the U.S. Treasury to finance large deficits without causing substantial upward pressure on short-term interest rates?

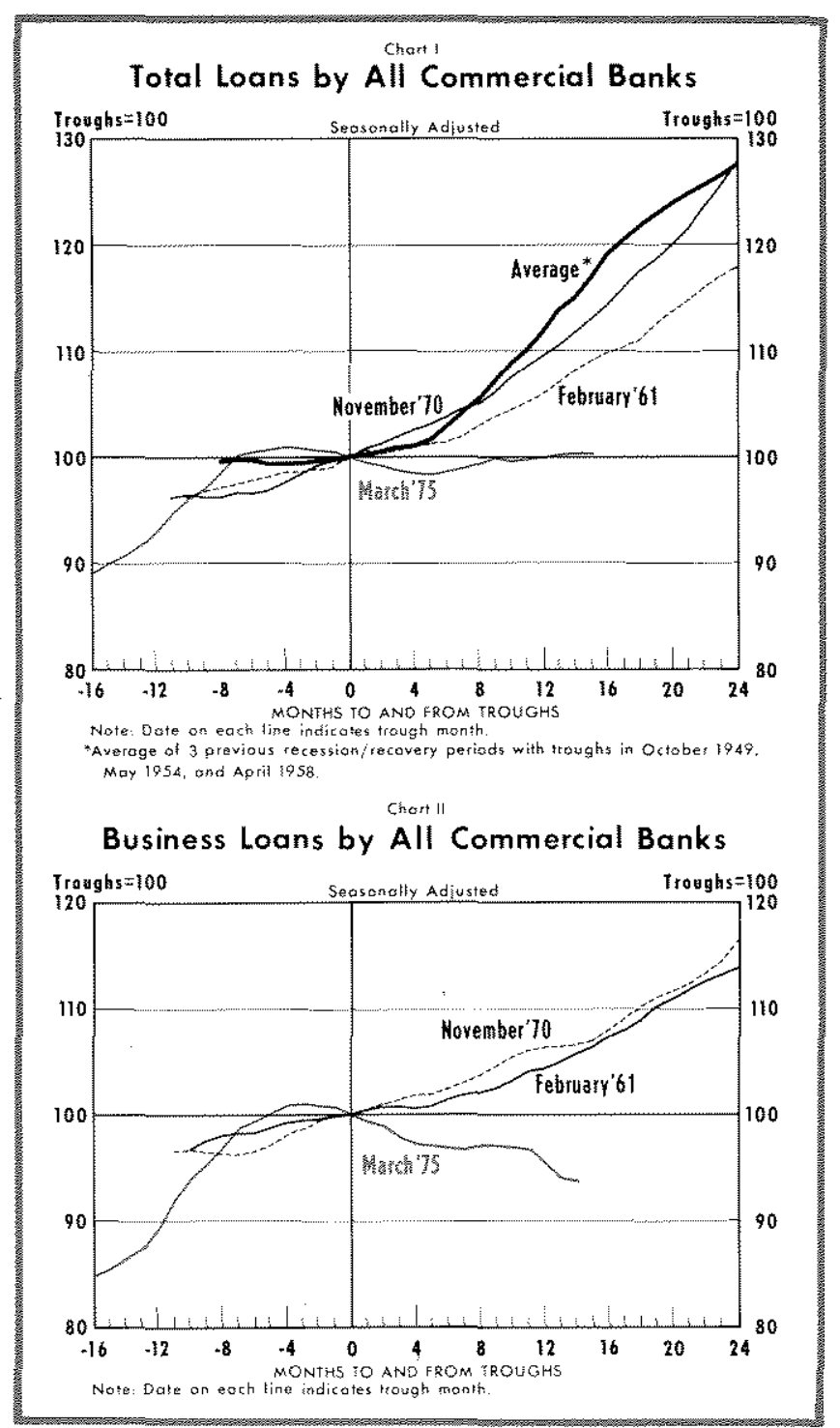




\section{HAV BANES BECOME MORE CONSERVATVE?}

Several events of the past two years would tend to make banks more conservative. Banks have sustained unusually large losses in the past two years, particularly on loans (see Table I for some historical comparisons). The Securities and Exchange Commission and the Federal bank regulatory agencies have been requiring banks to disclose more information on the risks they assume, and the press has published lists of "problem banks." In addition, bank regulators have been trying during recent years to get banks to increase their capital ratios, particularly the ratio of capital to riskier bank assets. ${ }^{1}$

The "banks have become more conservative" explanation of recent bank lending behavior is supported by several empirical observations. For one, banks have not reduced their loans to businesses because of a lack of available reserves. Bank loans plus investments have risen at a 5.1 percent anmual rate since March of last year, but almost all of this increase in earning assets has gone to investments, especially Federal Government debt. Investments as a percentage of the interest-earning assets of banks rose from 27 percent in the last quarter of 1974 (the low point for this ratio in recent years) to 32 percent in June of this year. This ratio rose to 34 percent in mid-1971 and declined steadily thereafter until early 1975.

As another possible indication of conservative behavior, banks have kept their announced prime lending rates high relative to the four- to six-month prime commercial paper rate - an alternative borrowing

1One of the major methods bank regulators have been using to induce banks to reduce their exposure to risk of failure is to deny applications by the most highly leveraged and poorly managed banking organizations to engage in new activities. For examples of such actions by the Federal Reserve Board, see discussions of cases in the following issues of the Federal Reserve Bulletin: June 1974, pp. 458-59; October 1974 , pp. 731-32; November 1974, pp. 791-93; December 1974, pp. $864-65$.
OSS RATIOS OF ALI COMMERCIAL BANMS

$110000010 \mathrm{~d}$ of dollores)

Percent of

1010140615 ?

00304

0374

0238

0309

0306

0492

0323

0566

0827

0643

0506

1053

0917

0784

0597

0803

0884

1212

1132

0978

0988

1853

41889

1384

.1576

235 .

0556
Lon los
los

53,333

34,226

36,258

33,090

55,574

40.111

48,623

80.812

67.113

08,442

48.525

196,176

175,656

153,062

276,578

236,300

305,428

401,780

4325.54

410.592

480750

981,608

1,087200

887,326

$1,159,187$

1056.031

$3,242,830$
Poreent of

Torol Assets?

0203

.0350

0220

0017

0187

0290

0257

0242

.0386

0310

0264

0204

00806

0688

0553

0760

.0758

0885

.1070

1073

0911

0067

11050

, 1886

1387

$-1571$

2050

35554

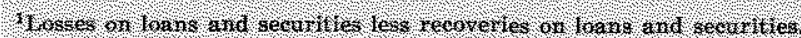

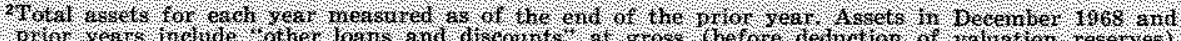

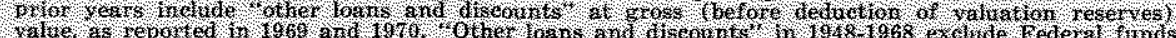

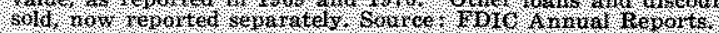

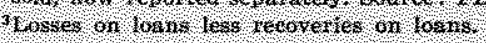

rate for larger firms. Since March of last year the differential between the prime rate and the commercial paper rate has averaged 1.4 percentage points, whereas that differential averaged 0.5 percentage point during 1971-74. Chart III compares the pattern of the differential between the prime rate and the commercial paper rate in the current recovery to the average differential and the range of that differential in comparable phases of four previous recoveries. ${ }^{2}$ Since last fall, the interest rate differential has been above the average differential for comparable periods of prior recoveries. In addition, for most of the period since early this year the interest rate differential has been greater than that posted for comparable periods of each of the five prior recoveries. The relatively

\footnotetext{
This interest rate differential tends to have a cyclical pattern which, therefore, must be conpared to its value in previous recession/recovery periods to determine whether it has been unusually large during recent months. See Richard T. Selden, Trends and Cycles in the Commercial Paper Market (New York: National Bureau of Economic Research, 1963), pp. $72-82$.
} 


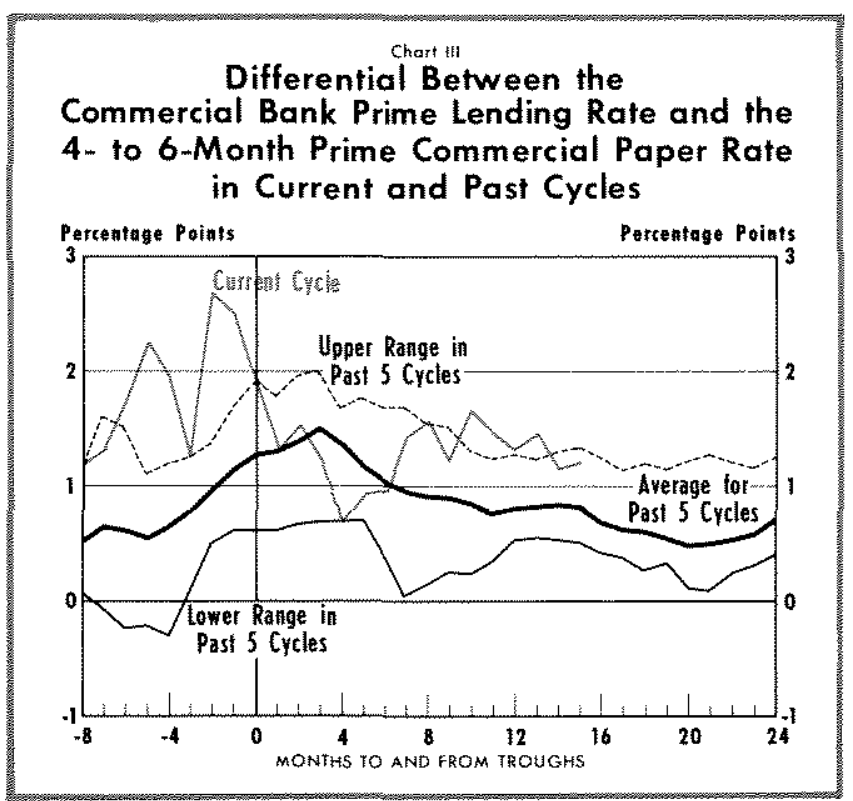

high prime rate is an apparent indication of reluctance by banks to expand their lending to businesses.

\section{WEAKNESSES OF TUE CONSRPVATVE

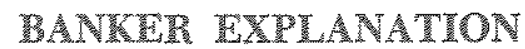

\section{Some Categonies of Loms Increase}

An indication that banks have not been unusually conservative in their lending practices in recent months is that, while business loans have declined, banks have increased their real estate and consumer loans. Mortgage debt held by all commercial banks rose 4.2 percent from the first quarter of 1975 to the first quarter of 1976. Consumer installment loans of all commercial banks began to increase after May of last year, rising at a 4 percent annual rate from May 1975 to April 1976.3 The pattems of change in real estate loans and consumer installment loans have been somewhat different at the larger commercial banks. Real estate loans of weekly reporting large commercial banks remained essentially unchanged during the year ending in March of this year, but have increased at a 9.8 percent annual rate in the last three months. Their consumer installment loans began rising after June of last year, increasing 7.9 percent from June of last year to June of this year.

A large share of bank loan losses in the past two years has been in real estate loans. A survey con-

\footnotetext{
3Consumer installment loans outstanding tend to begin rising about two months after the rate of economic activity begins to rise. See Philip A. Klein, The Cyclical Timing of Consumer Credit, 1920-67, Occasional Paper 113, National Bureau of Economic Research, 1971, p. 28.
}

ducted early this year indicates that the loans which banks expect to declare as losses this year are primarily real estate loans. ${ }^{*}$ Also, loss ratios tend to be higher on consumer lending than on lending to business. Therefore, these increases in real estate and consumer loans indicate that risk reduction has not become a dominant objective of commercial bank lending policies.

\section{Decline In Demand for Busines Credt}

Even though the commercial bank prime rate has been untsually high in relation to the commercial paper rate during the current recovery, there has not been a large-scale shift in credit demand by business firms from commercial banks to the commercial paper market. Commercial paper volume moved in its typical counter-cyclical pattern during the recent recession/recovery period, rising during the recession and declining for several months after the recession trough. ${ }^{5}$ From March 1975 to May 1976, the volume of commercial paper declined at a 2 percent annual rate.

Since borrowing from commercial banks and borrowing in the commercial paper market are primary sources of short-term credit for many large businesses, the sum of these two sources can be used as a measure of the demand for short-term business credit. If the decline in business loans by banks during the current recovery was just due to banks keeping their interest rates on loans uncompetitive with the commercial paper rate, the sum of business loans plus commercial paper volume would have tended to follow the usual recovery pattern. During previous recovery periods the sum of commercial bank loans to business plus commercial paper volume has risen a few months after recession troughs, whereas in the current recovery this measure of credit demand has declined (see Chart IV).

\section{The Changing Role of the Prime Rate}

Several recent news stories mention that banks have been offering loans below the stated prime rate to a greater extent during recent months than in the past. In addition, banks have been relaxing other terms of lending, such as compensating balance requirements. ${ }^{6}$ These stories about more bank loans at rates below

4Wall Street Journal, May 14, 1976, p. 10.

5Selden, Trends and Cycles in the Commercial Paper Matket, pp. $72-74$.

${ }^{6}$ American Banker, May 5, 1976, p, 1; Business Week, May 24, 1976, pp. 33-34. 


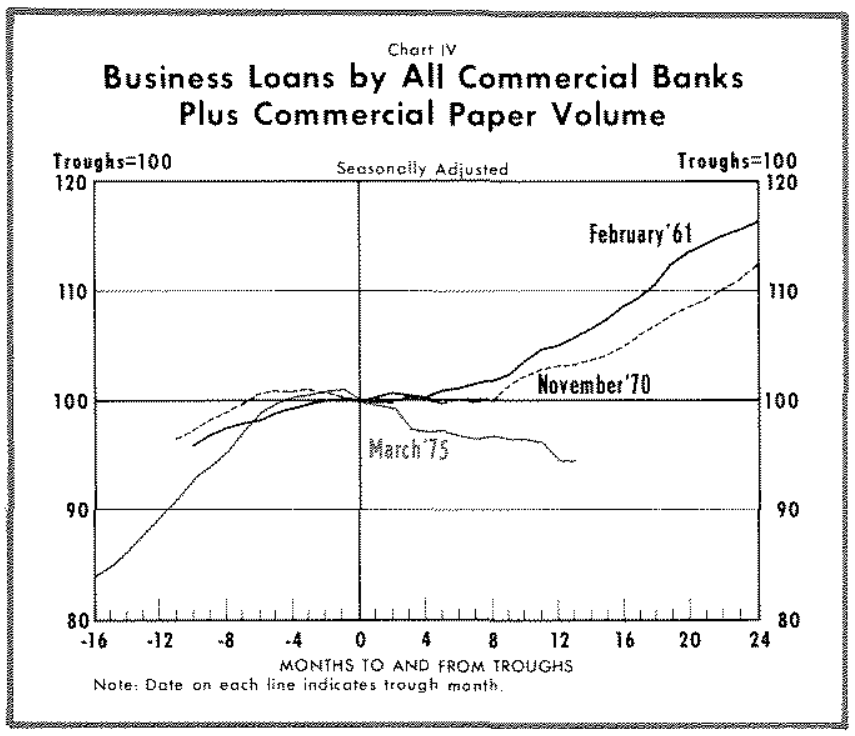

the prime rate are confirmed by surveys of interest rates on short-term business loans at a sample of large commercial banks. Table II presents the percentage of loans made at and below the prime rate for selected survey periods. ${ }^{7}$ The percentage of loans at interest rates below the prime rate increased in February and May of this year, although there was no marked rise in the percentage of loans made "at and below" the prime rate. The rise in the percentage of loans made at rates below prime was confined to loans of $\$ 1$ million and over. These observations raise doubts about the reliability of the difference between the commercial bank prime lending rate and the commercial paper rate as an indicator of conservative lending policies by banks.

Incentives for maintaining the stated prime rate high relative to alternative interest rates and making loans at less than the prime rate, as in the current recovery period, may be the result of banks having made business loans at interest rates that float with the prime rate. This policy has become widespread throughout the banking industry in recent years. ${ }^{8} \mathrm{By}$ making loans with floating rates, banks have forgone the windfall gains they formerly received during periods of interest rate declines, but have reduced the

In the sample, banks report the dollar amount and interest rate of each business loan $\$ 1,000$ and over made during the first seven business days of February, May, August and November of each year. The date each loan was made is not reported. The prime rate has changed diring several of these survey periods in recent years, creating difficulty in determining which loans were made at the prevailing prime rate. Observations in Table $I I$ are from surveys conducted during periods when the prime rate did not change.

8Richard B. Miller, "Everybody's Floating the Loan Rate," The Bankers Magazine (Spring 1975), pp. 42-45. risks of engaging in liability management during periods of widely fluctuating interest rates.

If interest rates on a bank's outstanding loans are not affected by prime rate changes, the bank's interest income on such loans will not be affected when the prime rate is adjusted. However, if banks make floating rate loans, a change in the prime rate does affect the interest income on outstanding loans as well as the volume of new loans attracted.

During the recent period of declining business demand for short-term credit, banks with floating interest rates on their outstanding loans have had incentives to keep their stated prime rates high and eam relatively high income on outstanding business loans until they are paid off. However, given the relatively large differential between the stated prime rate and other short-term interest rates, banks have had strong incentives to offer credit at less than the prime rate to firms which can also borrow in the commercial paper market, disregarding the conventional banking practice of using the prime rate as the minimum loan rate. ${ }^{9}$ As noted above the increase in loans at interest rates below the prime rate since last year has been primarily loans of $\$ 1$ million or more, which would be largely to firms that could also borrow in the commercial paper market.

\section{PXPLANATONS OF TWE DECLINL MN BUSTNESS LOANS}

Discarding the argument that banks have become more conservative, two reasons appear to explain the lack of bank financing in the current recovery:

(a) Businesses continued to reduce their inventories by large amounts and for an unusually long period of time into the current recovery.

(b) The volume of funds that business firms generate internally has increased even more rapidly during recent quarters than during previous recovery periods, reducing the external financing requirements of businesses. Banks have responded to the decline in business credit demand by significantly expanding their holdings of investments and increasing their loans in sectors of the economy in which demand for bank financing has been rising (including real estate and consumer loans) with the pace of economic activity.

9For an analysis of the role of the prime rate before floating rates became so common, see Donald Hodgman, Commercial Bank Loan and Investment Policy (Champaign, Illinois: University of Illinois, 1963). 




\section{Reduction in Inventories}

Changes in business inventories during the first four postwar business cycles were similar in amount and timing; the average changes in inventories during those recession/recovery periods are shown in Chart V. The 1970 recession was rather mild com-

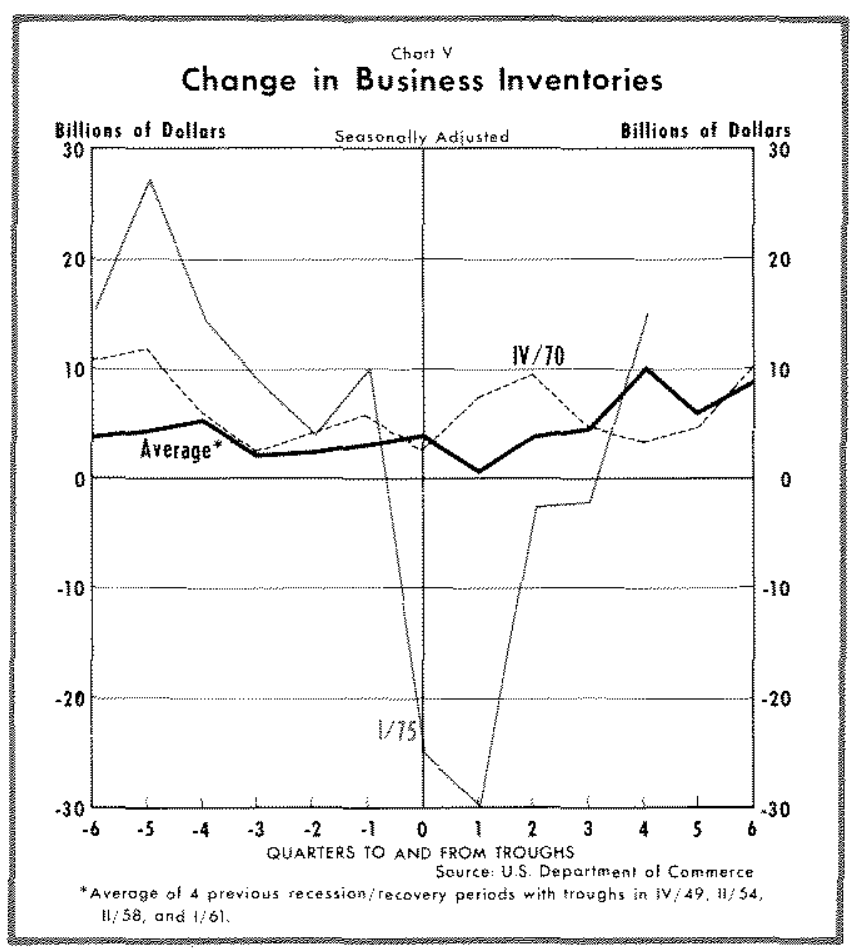

pared to other postwar recessions; firms were not induced to reduce inventories, but merely to reduce the rate of accumulation for one quarter. In contrast, inventory reductions beginning in late 1974 were unusually large and have continued for an unusually long period of time into the current recovery. Businesses finally began to increase their inventories in the first quarter of this year.

The unusually rapid accumulation of inventories during 1973 and much of 1974 was partially a reaction to shortages of various materials and products caused by wage and price controls and the real and expected effects of the reduction in the supply of energy. Also rapid price increases in late 1973 through the first three quarters of 1974 induced speculation on the prospects of inventory profits. The depth of the recession in 1974-75 reduced the prospects of inventory profits and gave businesses incentives for the rapid liquidation of inventories beginning late that year as inventories became excessive in relation to sales.

Statistical studies of the determinants of bank loans indicate that changes in business inventories have been primary determinants of changes in bank loans to businesses. ${ }^{10}$ Therefore, the large inventory reduc-

10Stephen M. Goldfeld, Commercial Bank Behavior and Economic Activity (Amsterdan: North Holland Publishing Co., 1966), pp. 82-86, 162; and Patric $\mathrm{H}$. Hendershott, "Recent Development of the Financial Sector of Econometric Models," Journal of Finance (March 1968), pp. 57-58, 62-65. 


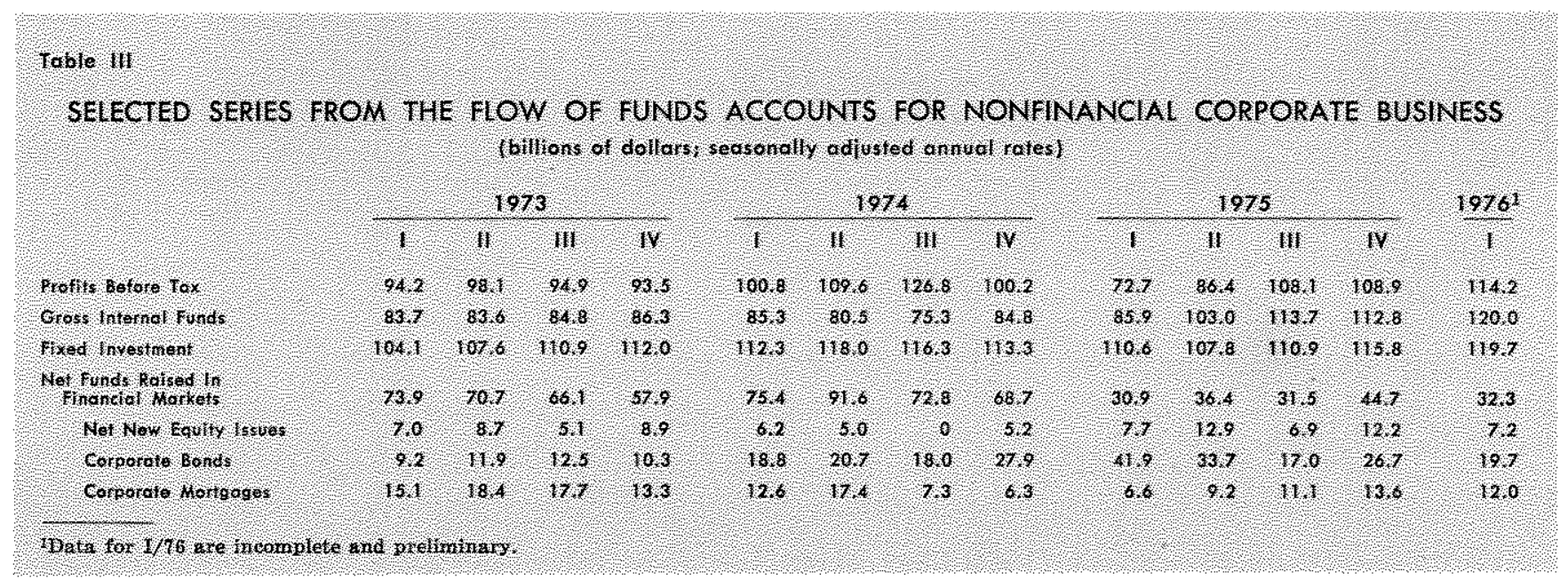

tions during the current recovery period can be considered a major cause of the declines in bank loans to businesses.

\section{Increase in Internally Generated Funds}

Table III presents several series from the flow-offunds accounts for the nonfinancial corporate sector in recent years. The series "Gross Internal Funds" measures retained earnings of nonfinancial corporations plus their capital consumption allowances, with some adjustments for foreign profits and changes in the value of inventories. The larger the increase in gross internal funds, the smaller the external financing requirements of firms tend to be, other things equal.

Gross internal funds increased 40 percent from the first quarter of 1975 to the first quarter of this year. This was a more rapid rate of increase than in the first year of each of the four previous recoveries. This relatively rapid expansion was due to a sharp acceleration in pre-tax corporate profits, which rose 57 percent from the first quarter of 1975 to the first quarter of 1976.

\section{Lengthening the Maturties of Business Riablities}

From the fourth quarter of 1974 to the first quarter of 1976 , net funds raised in financial markets by nonfinancial corporations increased $\$ 41.6$ billion. Funds raised from long-term sources (issuing equities, bonds, and mortgages) increased $\$ 57.1$ billion, and shortterm liabilities that had been incurred in financial markets were reduced by $\$ 15.5$ billion. ${ }^{11}$ Since fixed

11 These data were calculated by accumulating seasonally un adjusted quarterly changes in funds raised. Note that data in Table III are at seasonally adjusted annual rates. investment by corporations during the current recovery has been about equal to their internally generated funds ( see Table III), the increase in funds from long-term sources has not been used to finance increases in long-term assets; instead, such funds have been used to replace short-term debt in corporate balance sheets. This shift to long-term financing is largely a response to regular cyclical forces and the unusually large changes in business inventories discussed above.

As indicated in Chart VI the ratio of long-term funds raised by nonfinancial corporations to net total funds raised has increased during recession periods and remained relatively high for a few quarters after recession troughs. This pattern can be attributed to both a cyclical response in the allocation of business investment between inventories and fixed investment and to cyclical movements in the demand for financial credit and demand for equities.

Business firms tend to finance inventories from short-term borrowing and fixed investment from longterm borrowing, thereby attempting to match the length of time over which assets are held with the maturities of funds raised. Corporate fixed investment and inventory investment move pro-cyclically, with inventory investment more sensitive to reductions in aggregate demand. As discussed above, business firms do not begin rapid inventory accumulation until a few quarters after recession troughs. These cyclical patterns of fixed investment and inventory investment help explain the cyclical pattern of financing illustrated in Chart VI.

Total demand for credit in the economy tends to decline during recessions and rise as economic activity increases. Total net funds raised by nonfinancial corporations also move procyclically, but funds raised 


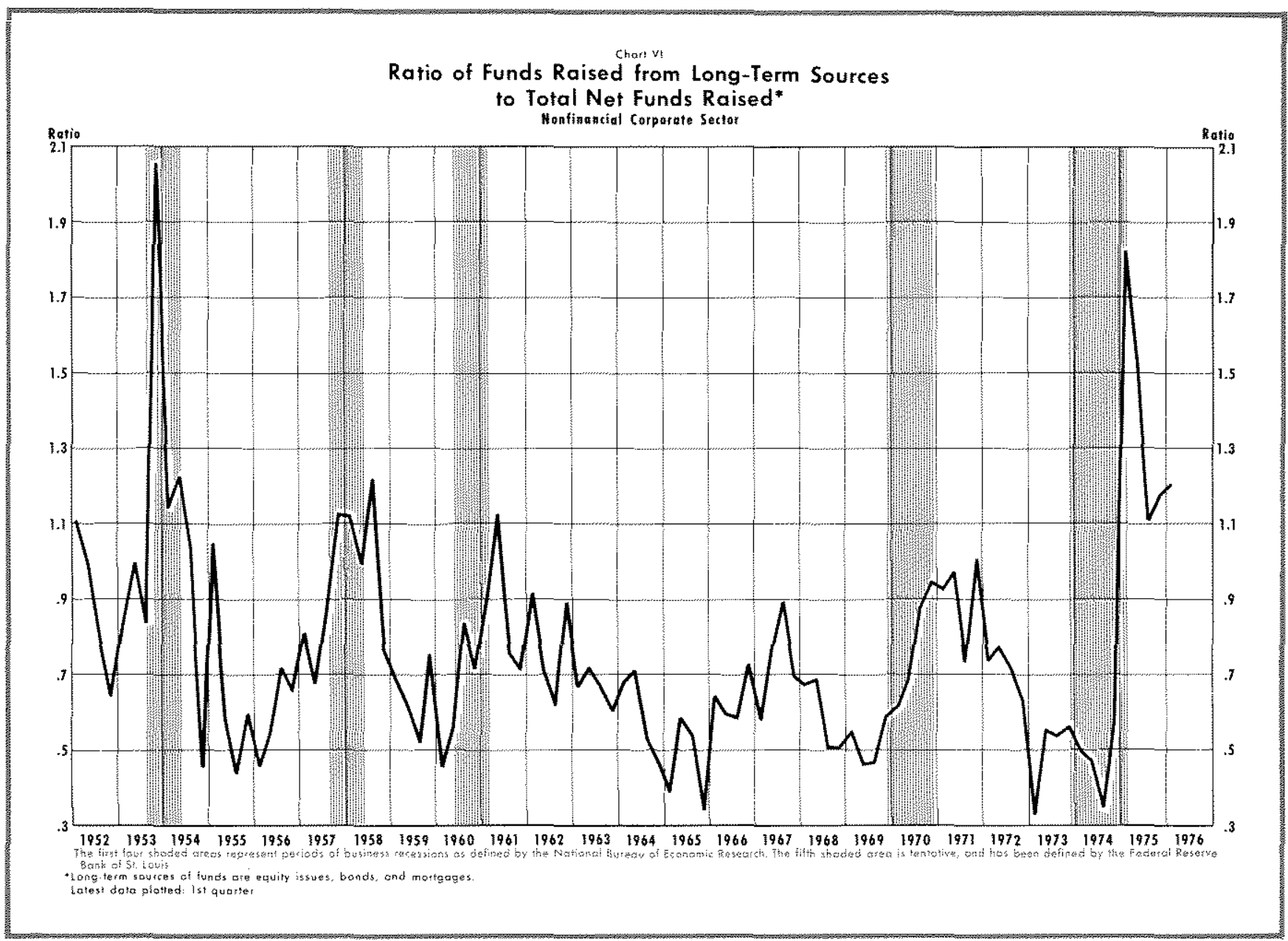

by nonfinancial corporations from issuing bonds and equity securities have different cyclical patterns.

The procyclical pattern of total credit demand tends to cause interest rates to move procyclically, including interest rates on long-term debt instruments. Business requirements for funds from long-term sources rise when economic activity is expanding and businesses are increasing their capital investments. Therefore, given the tendency for long-term interest rates to be lower during recessions than during the following periods of economic recovery, there is some incentive for businesses to do their longterm financing during recessions in anticipation of future increases in capital investment.

Changes in corporate debt over business cycles reflect such a financing strategy. Corporate bonds outstanding have increased more rapidly during the past five recessions than in periods just prior to those recessions, even though total net funds raised by nonfinancial corporations declined during those recession periods. ${ }^{12}$ Although long-term credit demanded by corporations increases during recession periods, the net effect of corporate credit demand, reduction in demand for credit by other sectors, and possible shifts in supply of credit due to reduced inflationary anticipations create a tendency for long-term interest rates to decline during recessions. One study traces this cyclical pattern of corporate financing back to $19000^{13}$

Typically, stock prices begin to rise a few months before recession troughs, as investors anticipate coming recoveries and corresponding rises in business profits. Rising stock prices, in turn, increase the

12These past five recessions include the most recent one ending around March 1975. The phase of the recent recession that was due to a decline in aggregate demand begar in the fall of 1974 , and that period is used as the cycle peak for purposes of examining the influences of declining aggregate demand on long-term interest rates and long-term borrowings by corporations. For an analysis of causes for the most recent recession, see Norman $\mathrm{N}$. Bowsher, "Two Stages of the Currext Recession," this Review (June 1975), pp. 2-8.

13W. Braddock Hickman, The Volume of Corporate Bond Fi. rancing Since 1900 (New York: National Bureau of Ecoromic Research, 1953), pp. 132-179. 
attractiveness to businesses of raising funds by issuing equity securities. During postwar business cycles equity issues by nonfinancial corporations have increased substantially during trough quarters and the first few quarters of recovery.

Corporate financing patterns during the recent recession and current recovery appear to reflect the usual cyclical influences plus that of the unusually large swings in inventory investment and liquidation. There may have been a more permanent shift in business preferences for more long-term financing, but not enough time has elapsed since the recent recession to distinguish such an influence from the cyclical tendencies in corporate finance.

\section{MMIICATIONS FOR FINANCIN FEDERAL PUDGET DEFITIS}

Commercial banks increased their holdings of Federal Government debt at a 57 percent annual rate from January 1975 to March 1976, largely in re- sponse to the decline in demand for bank loans by business firms. This reduction in demand for shortterm credit by businesses is one development which has made it possible for the Treasury to finance large budget deficits in 1975 and into 1976 without having put substantial upward pressure on short-term interest rates.

Business demand for short-term credit is likely to increase in the near future, as the incentives for inventory investment increase along with the general economic expansion. Corporate cash flow is likely to increase less rapidly in the future since corporate profits tend to rise less rapidly after the first year of an economic recovery. The shift in corporate financing to long-term sources during the recent recession and current recovery appears to be largely a cyclical phenomenon. As business demand for shortterm credit increases, the Federal Government will not be able to continue financing large budget deficits without putting some upward pressures on short-term rates.

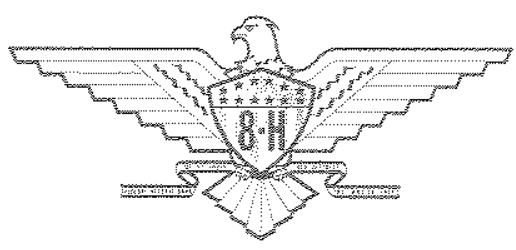

